\title{
(2) OPEN ACCESS \\ Differential diagnoses of pseudolymphomatous folliculitis: considerations as regards one case
}

\author{
José Bruno Mendoza Ramírez (D) ,' Dafne Ayala, ${ }^{2}$ Adrian Heald, ${ }^{3,4}$ \\ Gabriela Y C Moreno (1) ${ }^{3,5}$
}

${ }^{1}$ Department of Plastic and Reconstructive Surgery, Hospital General de Mexico Dr Eduardo Liceaga, State of Mexico, Mexico ${ }^{2}$ Phatology Department, Hospital Regional de Alta Especialidad de Ixtapaluca, Ixtapaluca, Mexico ${ }^{3}$ Division of Population Health, Health Services Research \& Primary Care, Faculty of Biology, Medicine \& Health, University of Manchester, Manchester, UK ${ }^{4}$ Endocrinology Department, Salford Royal NHS Foundation Trust, Salford, Manchester, UK ${ }^{5}$ Research Department, Dirección de Calidad y Educación en Salud, Secretaria de Salud de Mexico, Mexico City, Mexico

\section{Correspondence to}

Dr Gabriela Y C Moreno: gabriela.moreno@manchester. ac.uk

Accepted 23 December 2020

Check for updates

(c) BMJ Publishing Group Limited 2021. Re-use permitted under CC BY-NC. No commercial re-use. See rights and permissions. Published by BMJ.

To cite: Mendoza Ramírez JB, Ayala D, Heald A, et al. BMJ Case Rep 2021:14:e238291. doi:10.1136/bcr-2020238291

\section{SUMMARY}

Pseudolymphomatous folliculitis (PLF) is a rare disease of cutaneous lymphoid hyperplasia, with a low index of clinical suspicion. We present the clinical case of a 19-year-old male patient, with a solitary violet erythematous nodule of 6 months of evolution, located in the right infraorbital region, without presenting another symptomatology. Histopathological examination showed a lymphocytic infiltrate that surrounds the hair follicles, sebaceous and sweat glands that focally destroy their basement membrane. PLF was diagnosed based on histological and immunohistochemical studies. In the multiple studies and case reports, the variability of the initial clinical diagnosis never corresponds to PLF, becoming a pathology with a low suspect index.

\section{BACKGROUND}

Pseudolymphomatous folliculitis is a rare type of lymphoid hyperplasia with a benign curse, characterised by unique or multiple violet erythematous lesions in the shape of a dome that can be relapsing, ubicated on face, scalp and trunk. It resembles other types of hyperplasias, benign as well as malignant, that is clinically hard to distinguish, and it is required a histopathological and immunohistochemical differential diagnosis to be able to distinguish its treatment effectively. ${ }^{1}$ In this report, we present a case of pseudolymphomatous folliculitis localised on the right infraorbital region, with its clinical histological and immunohistochemical characteristics, including a table of differential diagnoses, their treatment and monitoring for 5 years.

\section{CASE PRESENTATION}

Male patient of 19 years old, born in Puebla and resident in the State of Mexico, student, came to dermatological consultation on September 2014, because of presenting a small papule on the right infraorbital region, with a gradual increase during the 6 consequent months to the appearing, until to achieve the current size. Important data of family history for the case: mother diagnosed with psoriasis and maternal grandmother diagnosed with vitiligo. No previous history of insect bites or local trauma, long-term solar exposing and previous use of topical steroid not specified for acne treatment before and while presenting the lesion, without showing any significant improvement. Before coming to dermatological consultation, the patient reported having received a treatment based on oral antibiotics and an attempt of percutaneous drainage with no remission of the lesion. During the examination, it was found a violet erythematous nodule on the right infraorbital region of approximately $1.5 \mathrm{~cm}$ of diameter, oval, soft, defined edges, with the presence of telangiectasias at the periphery, without reaching the centre, semisolid consistency and painless to palpation (figure 1A,B), also they were found multiple papules, pustules, open and closed comedones on the frontal region. The rest of the examination is without pathological data.

\section{INVESTIGATIONS}

With the above data, it was done a presumptive clinical diagnosis of lymphocytoma cutis, reason for making of an incisional biopsy of the lower half of the lesion for its histopathological study. The study reported a nonspecific chronic inflammatory process. In October 2014, a complete resection of the lesion was scheduled and also a new histopathological study was done. The result reported a lymphoproliferative process, of type non-Hodgkin's lymphoma of small cells, and it was suggested to make immunohistochemistry for its classification. In the same month, an immunohistochemical study was made and a new histological study too, which reported findings corresponding to pseudolymphomatous folliculitis (table 1) (figure 2A-J), without evidence of a malignant neoplastic process.

\section{DIFFERENTIAL DIAGNOSIS}

The differential diagnosis includes follicular mycosis fungoides, granulomatous rosacea, cutaneous marginal zone lymphoma, cutaneous lowgrade follicular lymphoma, small and medium-sized pleomorphic cutaneous T-cell lymphoma and other cutaneous pseudolymphomas (table 2$).^{2-6}$

\section{TREATMENT}

First of all, an incisional biopsy of the lower half of the lesion was done, then complete resection was scheduled. Pharmacological treatment was not necessary.

\section{OUTCOME AND FOLLOW-UP}

For 2 years of monitoring, illness recurrence was not observed. Later, the patient was referred to his family medicine unit, where he has been monitored for 2 more years without recurrence of the illness on its current state

\section{DISCUSSION}

Pseudolymphomatous folliculitis is a rare form of cunateous lymphoid hyperplasia, characterised by dense infiltration of lymphocytes, accompanied by 


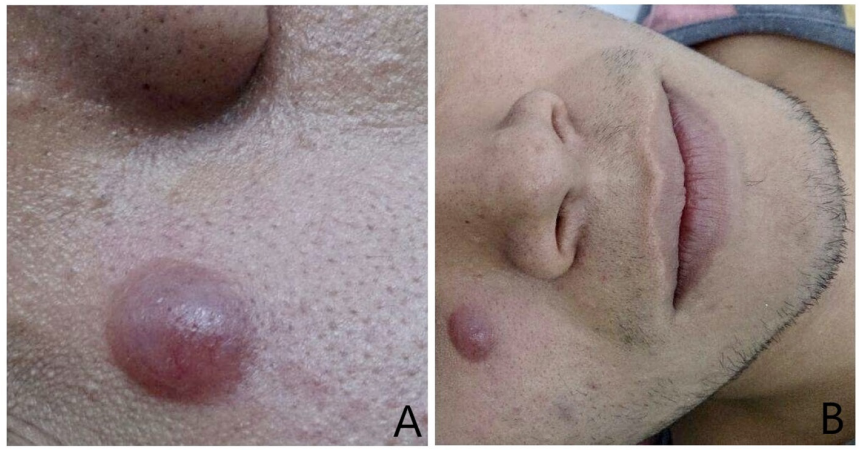

Figure 1 Clinical presentation. Dermatosis localised in the right infraorbital region, there is a violeterythematous nodule of $1.5 \mathrm{~cm}$ of diameter approximately, in the shape of a dome, with defined edges, with telangiectasias, firm and asymptomatic (A). Right infraorbital region lesion prior to the surgical resection $(B)$.

hyperplastic pilous hair follicles. There is no sex predominance and a wide range of age has been reported. ${ }^{56}$ The etiopathogenesis is unknown. Some theories have been proposed, like the existence of an antigen localised in the follicle, that might produce an exacerbated immune reaction. ${ }^{67}$ Supporting this theory, there is the presence of dendritic cells S100 and CDa1 positive in dense perifollicular clusters, suggesting a targeted process caused by an antigen that resides inside the follicle and its spontaneous remission after a biopsy that results in the elimination of the antigen in the lesion. Four cases have been reported with the previous history: one with insect bites precedents, two with trauma precedents and another one with the presence of Borrelia burgdorferi DNA. ${ }^{5-7}$

The lesions are localised in the facial region, especially on the cheek, nose, forehead and eyelid. In some cases, the lesions can happen on the scalp and upper trunk. In most of the cases, it is asymptomatic; nevertheless, mild symptomatology can appear, such as pain or itchiness. Its clinical presentation is characterised by a solitary nodule, erythematous or violet, in the shape of a dome, quick-growing, that can reach $3 \mathrm{~cm}$ of diameter. ${ }^{7-9}$ In most cases, the rash is isolated, but it can show an eruptive pattern with multiple lesions. ${ }^{9}$ During the dermatoscopy, prominent yellowish follicular and perifollicular patches have been observed, red follicular spots and arborizing 'treelike' vessels, although these are not findings specific of this illness. ${ }^{10}$ Histologically, a nodular dense or diffuse lymphocyte infiltrate has been observed, with many histiocytes and dendritic cells, localised from the dermis to the hypodermis, which surround and infiltrate the pilosebaceous unit deforming its walls. ${ }^{11} \mathrm{~A}$ characteristic is the formation of granulomas by histiocytes. In some

\begin{tabular}{ll}
\hline Table 1 & Immunohistochemistry report of the clinical case \\
\hline Immunohistochemistry report \\
\hline CD20 & Positive to B-cells \\
CD3 & Positive to T-cells \\
\hline Relación B-T & $1: 3$ \\
\hline CD4 & Positive \\
CD8 & Positive \\
Ratio CD4-CD8 & $2: 1$ \\
\hline Ki67 & $15 \%-20 \%$ \\
CDa1 & Positive on the dermis and diffuse epidermis on Langerhans cells \\
S100 & Positive on dendritic cells \\
\hline
\end{tabular}
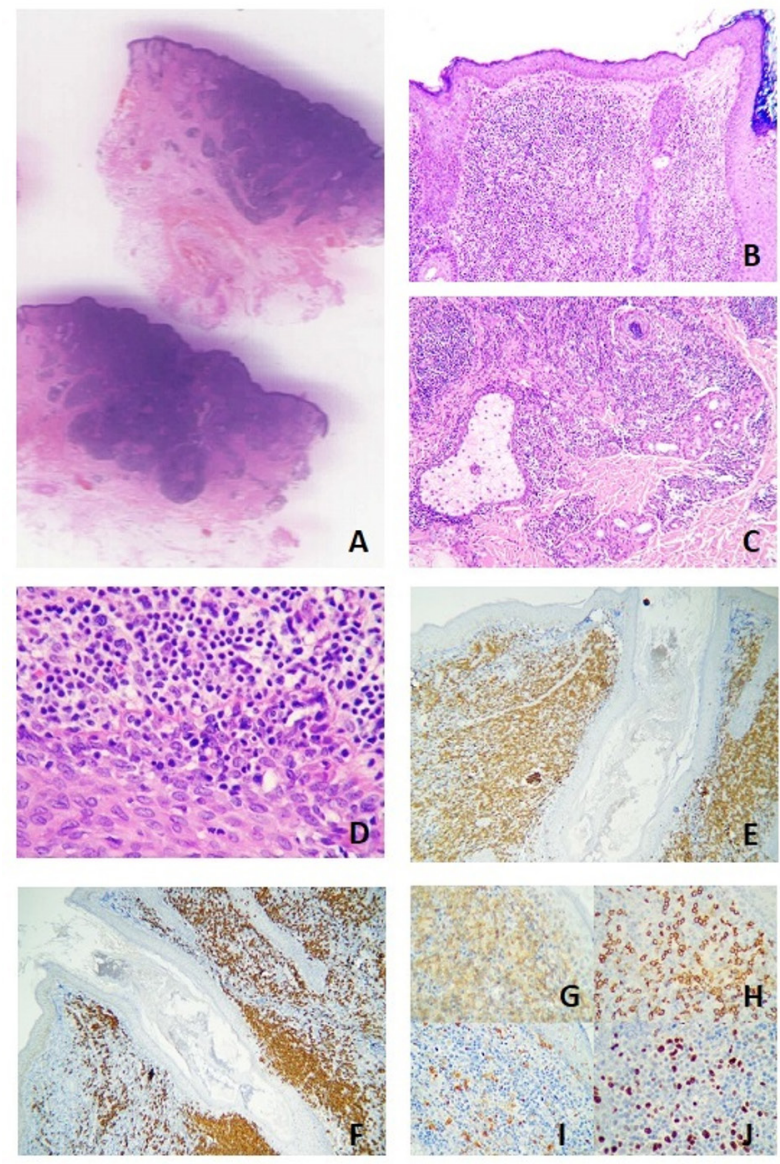

Figure 2 Histopathology and immunohistochemistry. Thin skin, extensive superficial and deep lymphocytic dermic infiltration (A), the lymphocytic infiltrate surrounds pilous follicles (B), sebaceous glands and sweat eccrine glands (C); in a focal way, there is destruction of the basement membrane (D), H\&E. The lymphocytic infiltrate has immunophenotype with a pattern of reactive type characterised by $B$ CD20 positive lymphocytes (E) and T CD3 positive (F) with a ratio of 1-3. The T CD4 positive lymphocyte population (G) and TCD8 positive $(H)$ has a pattern of reactive type, with ratio $2-1$. Also, S100 positive dendritic cells are identified (I) intraepidermal and dermic. the proliferation index of the lesion, measured with Ki67 (J) is 10\%-15\%.

cases, there can be the presence of plasma cells and eosinophils. ${ }^{12}$ The infiltrate is usually separated from the epidermis by a grenz zone. It has been used the term of 'follicular invasion' when the lymphocyte infiltrates bursts and destroys the epithelium of the follicles. Two types of follicular invasion can be recognised: in one of them, the follicles are destroyed. Finally they disappear, and, in the other one, the pilous follicles do not show any damage, but they are irritated and show hyperplastic changes with irregular forms on the follicle wall. ${ }^{11} 12$ Our case had both presentations: the pilous follicles, hyperplastic and irritated, with irregular forms and invasion with the destruction of its structure. Typically in the pseudolymphomatous folliculitis, changes on the pilous follicle are identified, they consist of irregular hyperplasia of the epithelium with deformation of the wall and, sometimes, with erased epithelium and delineated by a variable lymphocyte infiltrate. These changes in the follicle are known as 'follicle activation'. ${ }^{12}$ The immunohistochemistry reported a mixed population of B CD20 positive lymphocytes and T CD3, CD4 and CD8 positive lymphocytes, with a predominance of $\mathrm{T}$ cells $3: 1$, the protein $\mathrm{CDa} 1$ positive and $\mathrm{S} 100$ positive in perifollicular 


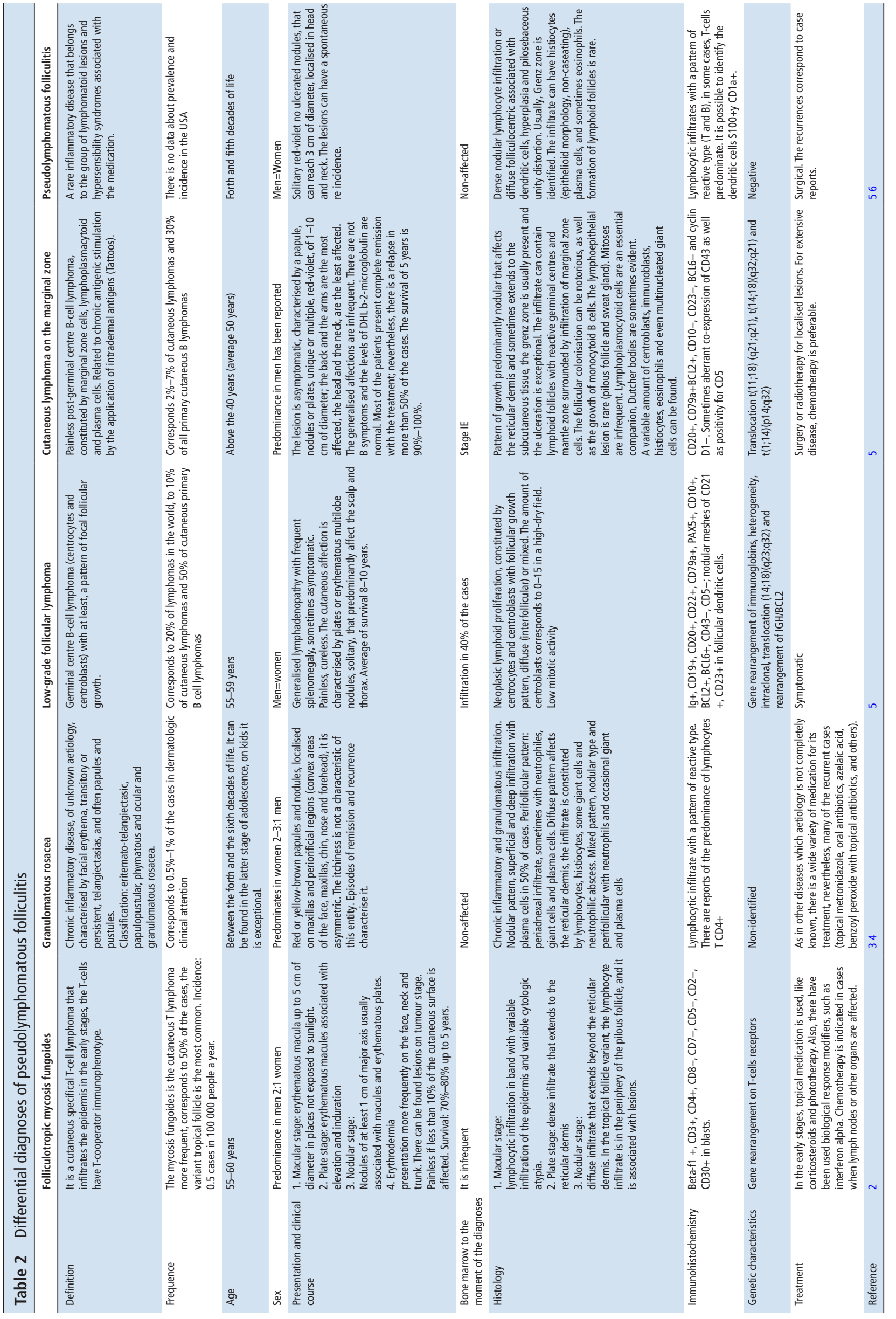


Patient's perspective

The experience I had during the process of this disease was like a shock to me since I had never been through a situation like this. It all started with a small lesion located on the infraorbital right side, at first, I believed it was something normal or insignificant, not paying attention to it. As time passed by, that small lesion started to increase its size, not other symptoms were related, with all this I started to believe it was something else, like an abscess or a papule, yet not giving it a lot of importance since I reckon-at some point this will decrease-it did not. Against all my thoughts, the lesion kept growing, it was until then that I decided to look for medical attention.

I visited a general practitioner who prescribed antibiotics and tried to drain the lesion, it seemed to be the right management. Still, my surprise was great when the only thing it drained was blood, instead of a purulent material as I thought it would be. At that point, when the uncertainty and fear were greater, I decided to visit a specialist in dermatology.

Six months later, the size of the lesion was bigger at the point that it partially occluded my vision when I looked down. I attended to my first medical consultation in dermatology, the doctor performed my medical history and explained to me that a biopsy test procedure was necessary to analyse those cells located in the suspicious area in order to confirm or rule out the presumptive diagnosis that was lymphocytoma cutis.

Afterward, when the biopsy procedure was finished, I went through a rough moment because there was an incision on my face, something that suddenly appeared there, something new that had never been there before, aesthetically talking it was acceptable, however, it was not easy to accept the change in my face. Despite all the explanations doctor gave to me, lots of doubts were rising: will I have an ugly scar? Will my face look the same? Which is the diagnosis? Is my life endangered? Is all this my fault for being overexposed to the sun without any protection?

Two weeks later, I received a phone call, it was my doctor telling I had to make a medical appointment as soon as possible since the results of the biopsy were ready, nothing else was said. I attended the next day to my medical consultation, at that time I felt calm as the scar on my face looked so much better. She showed and explained to me that I had an unspecified chronic inflammatory process and that it was necessary to carry out another histological study with the remaining lesion and that I had to have this removed as there was a possibility that I might be facing a neoplastic disease, as I heard that, immediately felt really bad, all I had in my mind was: another surgical procedure, another scar, starting a new recovery time and the most important the fact this papule might be due to a neoplastic process, my thoughts went to the worst scenario, not to mention I was attending to my second year of medical school, so I was not only having stress in my academic area but also my personal and health areas. It was difficult for me, but at the end, I accept it all and the surgery was scheduled to be performed in October.

In October, I went to the hospital where the operation was going to take place. The doctor explained everything well. She briefed me about everything, saying a wider incision was necessary to achieve an accurate aesthetic result.

After the operation I felt shocked as I saw the size of the surgical wound, I told myself 'well, at least I have no longer that awful papule' but then, every time I look at myself, at my face,

Continued

\section{Patient's perspective Continued}

I really felt an emotional impact. Also, when the anaesthesia ended, I felt pain and the wound was bleeding.

In a couple of weeks, they told me the results of the further biopsies. The skin tumour was a lymphoproliferative process of the non-Hodgkin lymphoma type that required to be precisely classified, which implied additional histological and more sophisticated studies. By that time, my parents fell down and I did not realised how big this problem was, how serious was to have this type of cancer and to think that this skin clinical manifestation was the reflection of something else happening inside my body. All I needed and wanted to know was 'what do I need to do now to improve my health status? Which is the most accurate treatment? How can I help my parents?' since the most affected ones were they, I mean getting the news that your only child has cancer might be shocking.

Following the next 2 weeks I had my third appointment, I must admit the dermatology specialist and doctors were all fantastic all the time and explained to me things really well during all this process, this made me feel confident and cared by all of them. At this point, I had already had enough time to accept my disease and I purposed myself to fight against it and to do all my best. Doctor explained to my parents and me that the results of the new studies were interpreted by a group of experts on histopathology; specifically the immunohistochemical tests helped to dictate a new diagnosis, which was pseudolymphomatous folliculitis, a rare benign disease that affects a small group of people, this all meant I did not have cancer and just needed regular medical checkups. The announcement made my parents smile and I was reassured to know that no other treatment was required.

Nowadays, after a couple of years, there was no recurrence of this disease.

To me, it is a pleasure and an honour to be able to write about my clinical case, the presentation of this indolent pathology. One of the main purposes is to emphasise the importance of the clinical dermatological lesions due to that some may be similar to those present in some differential diagnosis. I would like to thank all doctors who were present during this process, not only for helping my family and me but also for supporting the idea of sharing this information to the scientific community.

dendritic cells, typical features of pseudolymphomatous folliculitis. ${ }^{11-13}$ The expression of the PD-1 marker in T lymphocytes has been reported. ${ }^{13}$ The proliferation index (Ki67) was positive from $15 \%$ to $20 \%$, the Ki67 can be variable as it is reported on the study by Granados-Lopez et al in which they got a rank of Ki67 from $6 \%$ to $40 \%$ in their study with 19 patients. ${ }^{14}$ There is not a restriction of chains $\kappa / \lambda$. Although the pseudolymphomatous folliculitis behaves like benign hyperplasia, it is necessary the differentiation of the malignant cutaneous lymphoma and related pathologies through histological and immunohistochemical studies. The differential diagnosis, according to the case reports, includes cutaneous marginal zone lymphoma, small and medium-sized pleomorphic cutaneous T-cell lymphoma, cutaneous low-grade follicular lymphoma, follicular mycosis fungoides, granulomatous rosacea and other cutaneous pseudolymphomas (table 2). ${ }^{1-14}$ The first-line treatment is the excisional biopsy. The use of antimalarials, methotrexate, triamcinolone acetonide, tacrolimus $0.1 \%$ and cyclosporine have been reported with a variable success rate, these treatments can be an option in 
residual or multiple lesions. ${ }^{911} 15$ The use of intralesional corticosteroid is recommended when the excision cannot be completed, having good outcomes. ${ }^{15}$ In some cases, a spontaneous remission has been reported after the incisional biopsy. ${ }^{16}{ }^{17}$ Although there are no reports of the pseudolymphomatous folliculitis that progresses to a malignant lesion, some authors recommend close monitoring for a period of 6-12 months because of the probability of spontaneous recurrence. ${ }^{18}{ }^{19}$ In our study, we followed up for the 5 next years without showing any recurrence of the disease.

\section{Learning points}

- The pseudolymphomatous folliculitis islymphoid cutaneous hyperplasia was hard to diagnose because clinically it can resemble a wide variety of dermatological pathologies, benign as well as malignant because of the absence of specific signs and symptoms of the disease.

- In most of the cases, it is asymptomatic; nevertheless, mild symptomatology can appear such as pain or itchiness. Its clinical presentation is characterised by a solitary nodule, erythematous or violet, in the shape of a dome, quickgrowing, that can reach $3 \mathrm{~cm}$ of diameter; however, these are not findings specific of this illness. The lesions are localised in the facial region, especially on the cheek, nose, forehead and eyelid. In some cases, the lesions can happen on the scalp and upper trunk.

- Histologically, a nodular dense or diffuse lymphocyte infiltrate with many histiocytes and dendritic cells, localised from the dermis to the hypodermis, that surrounds and infiltrate the pilosebaceous unit deforming its walls. The immunohistochemistry is characterised by a mixed population of $B$ CD20 positive lymphocytes and T CD3, CD4 and CD8 positive lymphocytes, with a predominance of $\mathrm{T}$ cells $3: 1$, the protein $\mathrm{CDa} 1$ positive and $\mathrm{S} 100$ positive in perifollicular dendritic cells.

- It is important to correctly assess the diagnoses supported by histological and immunohistochemical studies to avoid the unnecessary use of treatments and procedures such as radiotherapy, chemotherapy, biological response modifiers, percutaneous drainages or oral antibiotics for pathology with a benign development.

\section{Twitter Gabriela Y C Moreno @gab_ilu}

Acknowledgements To Maria Fernanda de las Torres Robles and Genoveva Villavicencio for their collaboration during the making of this work.

Contributors GYCM and JBMMR wrote the manuscript with support from DA who is carried out the histopathology. AH contributed the final version of the manuscript. GYCM supervised the case report.

Funding The authors have not declared a specific grant for this research from any funding agency in the public, commercial or not-for-profit sectors.
Competing interests None declared.

Patient consent for publication Obtained.

Provenance and peer review Not commissioned; externally peer reviewed.

Open access This is an open access article distributed in accordance with the Creative Commons Attribution Non Commercial (CC BY-NC 4.0) license, which permits others to distribute, remix, adapt, build upon this work non-commercially, and license their derivative works on different terms, provided the original work is properly cited and the use is non-commercial. See: http://creativecommons.org/ licenses/by-nc/4.0/.

\section{ORCID iDs}

José Bruno Mendoza Ramírez http://orcid.org/0000-0002-9103-0314

Gabriela Y C Moreno http://orcid.org/0000-0002-4506-8223

\section{REFERENCES}

1 Horikiri M, Abe N, Ueda K. Multiple nodules on the left cheek represented pseudolymphomatous folliculitis. Clin Case Rep 2016;4:568-71.

2 Hsi ED. Hematopathology. Philadelphia Elsevier, 2018: 306-39.

3 Sarmiento LM, Ponce OR, Mercadillo PP. Informe de un caso Y revisión de la literatura. Revista medica del Hospital General de Mexico SS, 2008: 204-8.

4 Buhl T, Sulk M, Nowak P, et al. Molecular and morphological characterization of inflammatory infiltrate in rosacea reveals activation of Th1/Th17 pathways. $J$ Invest Dermatol 2015;135:2198-208.

5 Calonje E, Brenn T, Lazar A. McKee's Pathology of the Skin with Clinical Correlations. Elsevier Health Sciences, 2012: 1311-420.

6 Arai E, Shimizu M, Hirose T. A review of 55 cases of cutaneous lymphoid hyperplasia: reassessment of the histopathologic findings leading to reclassification of 4 lesions as cutaneous marginal zone lymphoma and 19 as pseudolymphomatous folliculitis. Hum Pathol 2005;36:505-11

7 Kazakov DV, Belousova IE, Kacerovska D, et al. Hyperplasia of hair follicles and other adnexal structures in cutaneous lymphoproliferative disorders: a study of 53 cases, including so-called pseudolymphomatous folliculitis and overt lymphomas. Am J Surg Pathol 2008;32:1468-78.

8 Ruiz MJM, Vásquez RM, Puebla MM. Foliculitis pseudolinfomatosa: reporte de caso. Dermatología Cosmética, Médica y Quirúrgica 2020;18:111-4.

9 Nakamura M, Kabashima K, Tokura Y. Pseudolymphomatous folliculitis presenting with multiple nodules. Eur J Dermatol 2009;19:263-4.

10 Fujimura T, Hidaka T, Hashimoto A, et al. Dermoscopy findings of pseudolymphomatous folliculitis. Case Rep Dermatol 2012;4:154-7.

11 Gutte RM. Pseudolymphomatous folliculitis: a distinctive cutaneous lymphoid hyperplasia. Indian J Dermatol 2013;58:278-80.

12 Kwon EJ, Kristjansson AK, Meyerson HJ, et al. A case of recurrent pseudolymphomatous folliculitis: a mimic of cutaneous lymphoma. J Am Acad Dermatol 2009:60:994-1000.

13 Goyal A, Moore JB, Gimbel D, et al. Pd-1, S-100 and CD1a expression in pseudolymphomatous folliculitis, primary cutaneous marginal zone B-cell lymphoma (MALT lymphoma) and cutaneous lymphoid hyperplasia. J Cutan Pathol 2015;42:6-15.

14 Granados-López SL, Tousaint-Caire S, Moreno-Collado C, et al. [Pseudolymphomatous folliculitis: a study of the clinicopathologic and immunohistochemical characteristics of 19 cases and their diagnostic differential]. Gac Med Mex 2014;150 Suppl 2:232-41.

15 Lee H-W, Ahn S-J, Lee M-W, et al. A case of pseudolymphomatous folliculitis. J Eur Acad Dermatol Venereol 2006;20:230-2.

16 Kakizaki A, Fujimura T, Numata I, et al. Pseudolymphomatous folliculitis on the nose. Case Rep Dermato/ 2012:4:27-30.

17 Dargent JL, Debois J, Sass U, et al. Unusual T cell pseudolymphoma with features of so-called pseudolymphomatous folliculitis. Dermatology 2002;204:159-61.

18 Sanchis-Sánchez C, Santos-Alarcón S, Benavente-Villegas FC, et al. Red nodule on the face with "spontaneous" regression. An Bras Dermatol 2017;92:135-7.

19 MÁ F, Sánchez MD, García M. Foliculitis seudolinfomatosa. PIEL formación continuada en dermatología 2016;31:728-30. 
Copyright 2021 BMJ Publishing Group. All rights reserved. For permission to reuse any of this content visit https://www.bmj.com/company/products-services/rights-and-licensing/permissions/

BMJ Case Report Fellows may re-use this article for personal use and teaching without any further permission.

Become a Fellow of BMJ Case Reports today and you can:

- Submit as many cases as you like

- Enjoy fast sympathetic peer review and rapid publication of accepted articles

- Access all the published articles

- Re-use any of the published material for personal use and teaching without further permission

Customer Service

If you have any further queries about your subscription, please contact our customer services team on +44 (0) 2071111105 or via email at support@bmj.com.

Visit casereports.bmj.com for more articles like this and to become a Fellow 